\title{
Accessing the genetic content of Xylocopa frontalis bees (Apidae, Xylocopini) for sustainable management in pollination services of passion fruit
}

\author{
Jayça Amate Marim Toledo ${ }^{1}$, Camila Nonato Junqueira ${ }^{2}$, Solange Cristina Augusto ${ }^{3}$, \\ Maria Cristina ArIAs ${ }^{4}$, Rute Magalhães Brito ${ }^{1}$ \\ ${ }^{1}$ Universidade Federal de Uberlândia, Instituto de Genética e Bioquímica, Campus Umuarama, Uberlândia, MG CEP \\ 38400-902, Brazil \\ ${ }^{2}$ Universidade Federal de Uberlândia, Escola Técnica de Saúde, Campus Umuarama, Uberlândia, MG CEP 38400-902, \\ Brazil \\ ${ }^{3}$ Universidade Federal de Uberlândia, Instituto de Biologia, Campus Umuarama, Uberlândia, MG CEP 38400-902, \\ Brazil \\ ${ }^{4}$ Universidade de São Paulo, Instituto de Biociência, Cidade Universitária, São Paulo, SP CEP 05508-090, Brazil
}

Received 8 September 2016 - Revised 27 April 2017 - Accepted 1 June 2017

\begin{abstract}
The commercial use of pollinators can be beneficial to many crops. In the case of passion fruit, the supply of nests of Xylocopa frontalis in crop areas was shown to be effective for the improvement of the production and quality of fruits, but little is known about how the manipulation of native bees could change the genetic patrimony of local populations. The aim of this study was to describe the genetic composition of $X$. frontalis bees attracted to two agroecosystems, one natural reserve and one urban area based on mitochondrial DNA (partial sequencing of the gene cytochrome oxidase I) and microsatellite markers. One of the study areas comprised most of the exclusive haplotypes (50\%); however, the microsatellite data showed no structuring between areas. Based on our data, we suggest a plan for exchanging nests of $X$. frontalis to passion fruit areas taking into account the genetic composition of local populations, avoiding then disturbances to their natural genetic patrimony.
\end{abstract}

\section{Xylocopa frontalis / mtDNA / microsatellites / pollination service / bees' management}

\section{INTRODUCTION}

The decline of pollinators, especially bees, and the consequent reduction in food production is a major concern for scientists and has received great emphasis as a global phenomenon (Potts et al. 2010). Human activities such as deforestation, habitat fragmentation, and insecticide use have led to the loss of nests of a variety of bee species (Potts et al. 2010; Goulson et al. 2015). Consequently, bee populations have become isolated

Corresponding author: R. M. Brito, brito.rm@ufu.br Manuscript editor: Alexandra Klein
(Steffan-Dewenter and Tscharntke 1999; Freiria et al. 2012), which could cause inbreeding depression and even local extinctions (Ellstrand and Elam 1993; Zayed 2009; Wang and Bradburd 2014). Such factors may have severe consequences, such as low productivity in agroecosystems that depend on wild bees for pollination (Aizen et al. 2009; Freitas and Pinheiro 2010).

Some species are commonly used for pollination services such as the alfafa leafcutting bee (Megachile rotunda) in North America (USA and Canada) (Pitts-Singer and Cane 2011) and Bombus terrestris, in Europe (Velthuis and van Doorn 2006). Nevertheless, the species most widely used is Apis mellifera (vanEngelsdorp 
and Meixner 2010). The introduction of hives in crop areas has been associated with an increase of productivity of apples (Malus domestica Borkh), berries (Vaccinium spp.), cantaloupes (Cucumis spp.), and almonds (Prunus dulcis Mill) (Losey and Vaughan 2006). However, A. mellifera may not be an efficient pollinator of some crops with large flowers, in which anthers and/or stigma are not touched due to its small body size. This is the case with yellow passion fruit (Passiflora edulis $\mathrm{f}$. flavicarpa Deneger) (Camillo 2003) for which large solitary bees of the genus Xylocopa are the main pollinators (Pereira and Garófalo 2010; Yamamoto et al. 2012; Junqueira et al. 2013; Junqueira and Augusto 2016). In southeastern Brazil, Xylocopa frontalis is one of the most frequent species in passion fruit crop areas (Yamamoto et al. 2012; Junqueira et al. 2013) and presents great management potential as it is easily reared in trap-nests (Junqueira et al. 2012). Nest management techniques which include the introduction of nests and trap-nests for $X$. frontalis in passion fruit areas was shown to be effective for increasing the production and the sweetness of the fruits (Junqueira et al. 2013; Junqueira and Augusto 2016).

In Brazil, passion fruit production can reach over 800,000 t per year (IBGE 2013) and supplies almost entirely the internal market for fresh consumption and the juice industry (Meletti 2011). Factors such as the adoption of proper production technology, the use of genetically improved cultivars, and the increased demand combine to boost production numbers (Meletti 2011). However, a major difficulty for the production, which predominantly occurs in small properties, is the manpower to carry out cross-pollination (Pimentel et al. 2009).

The increase of Xylocopa bees in crop areas through the introduction of active nests is a promising strategy to reduce the pollination deficit, which limits the commercial production (Junqueira and Augusto 2016). Although the management of wild bees has been used successfully for producing fruits with a greater number of seeds and of better quality (Heard 1999; Slaa et al. 2006; Oliveira and Schlindwein 2009; Lowenstein et al. 2015; Junqueira and Augusto 2016), little is known about how this anthropic movement of native bees (Brown and Paxton 2009) for the purpose of pollination services could change the genetic patrimony of local populations.

The introgression of new haplotypes or alleles between populations may lead to the homogenization of the populations' gene pool. A rare allele can be replaced by a common one from a different area (Olden et al. 2004; Campbell et al. 2016), and the loss of genetic variability of locally adapted populations can be disadvantageous to species in the long term, changing for instance the capacity to expand its distribution or increase vulnerability to the invasion of competitors (Olden et al. 2004).

Hence, strategies for Xylocopa bees management aiming at passion fruit pollination should be designed based on the identification of management units (MUs), which are populations with significant genetic divergence (mitochondrial or nuclear) but not necessarily presenting reciprocal monophyly (Moritz 1994). The identification of MUs is performed through the analysis of the populations' genetic diversity such as genetic distance, gene flow, shared alleles, or reciprocal monophyly based on the genetic diversity of cytoplasmic or nuclear genomes (Moritz 1994).

The aim of this study was to analyze the genetic composition of $X$. frontalis bees attracted to trapnests in four study areas based on mitochondrial DNA (partial sequencing of the gene cytochrome oxidase I) and microsatellites. The knowledge about the genetic composition of these local populations can help us in the management of nests aiming at increasing the natural passion fruit pollination, considering that this procedure consists of transference of nests from breeding to crop areas.

\section{MATERIAL AND METHODS}

\subsection{Study areas}

Females of $X$. frontalis were attracted using trap-nests available in bee shelters. All bees (founders and offspring) were tagged on the thorax with a code specific for each breeding area. These bee shelters, as described by Junqueira et al. (2012), were built in four areas in the municipality of 
Uberlândia, Minas Gerais State, Brazil (Table I): (i) Água Limpa Experimental Farm (ALEF) corresponds to a mixed vegetation system, which includes savannah formations and gallery forest, as well as experimental crops such as soybeans, corn, mango, acerola, passion fruit, and pineapple; (ii) Glória Experimental Farm (GEF) includes agropastoral areas and a semideciduous forest and gallery forest remnant of 30 ha; (iii) Ecological Station of Panga (ESP) includes only forest and savannah formations (Schiavini and Araújo 1989); and (iv) Universidade Federal de Uberlândia, Campus Umuarama (UFU-UMU), an urban area, is mainly occupied by buildings with few green areas with both native and exotic plant species.

These areas were chosen to breed $X$. frontalis for the management and transference of nests to passion fruit crop areas to increase the natural fruit set. These bee shelters have been mantained since 2005 (ALEF, ESP, and UFU-UMU) and 2010 (GEF).

\subsection{Tissue collection and extraction of DNA}

We used nonlethal methodology (Arias et al. 2013) for tissue collection from 64 individuals: 21 in ALEF, 17 in GEF, 14 in PES, and 12 in UFUUMU.

Bees were removed from trap-nests and placed in modified plastic syringes (see Yamamoto et al. 2014), and with the aid of scissors, the pretarsal and one or two tarsomeres were removed from the second pair of legs (Arias et al. 2013) for DNA extraction using the Chelex method (Walsh et al. 1991).

\subsection{Mitochondrial DNA}

Mitochondrial haplotypes were obtained from the sequencing of $600 \mathrm{bp}$ of cytochrome oxidase I (COI) gene using mtD6 and mtD9 primers (Simon et al. 1994), following the methodology described by Francisco et al. (2011). The fragments were analyzed in genetic analyzer ABI 3730 through the sequencing service at the Institute of Chemistry of the University of São Paulo. Sequence data has been submitted to GenBank under the accession numbers KY508962-KY509015.

The sequences were aligned using the GENEIOUS 5.1.6 program (Drummond et al. 2010). The mitochondrial genetic diversity of bees in the areas was accessed from nucleotide diversity, and haplotype diversity data obtained using DNASP 5.10.1 program (Rozas et al. 2010). Population structuring was analyzed by calculating genetic Nei's distance (Nei 1978) and analysis of molecular variance (AMOVA) (Excoffier et al. 1992) using GENALEX 6.5 program (Peakall and Smouse 2012). A phylogenetic tree of maximum likelihood was constructed using MEGA software v 5.1 (Tamura et al. 2011) to check if there would be any reciprocal monophyly between the areas, a requirement for MU detection (Moritz 1994). We also built a network to

Table I. Study areas, geographical coordinates, size in hectares (ha), and distance in kilometers $(\mathrm{km})$ among the study areas: ALEF (Água Limpa Experimental Farm), GEF (Glória Experimental Farm), ESP (Ecological Station of Panga); and UFU-UMU (Universidade Federal de Uberlândia)

\begin{tabular}{llllll}
\hline Study areas & Coordinates & Size (ha) & \multicolumn{2}{l}{ Distance (km) } & \\
\cline { 3 - 5 } & & & GEF & ESP & UFU-UMU \\
\hline ALEF & $19^{\circ} 05^{\prime} 48^{\prime \prime} \mathrm{S} / 48^{\circ} 21^{\prime} 05^{\prime \prime} \mathrm{W}$ & 300 & 22.0 & 7.8 & 25.0 \\
GEF & $18^{\circ} 57^{\prime} 03^{\prime \prime} \mathrm{S} / 48^{\circ} 12^{\prime} 22^{\prime \prime} \mathrm{W}$ & 685 & & 31.2 & 8.8 \\
ESP & $19^{\circ} 10^{\prime} 04^{\prime \prime} \mathrm{S} / 48^{\circ} 23^{\prime} 41^{\prime \prime} \mathrm{W}$ & 403.85 & & & 32 \\
UFU-UMU & $18^{\circ} 53^{\prime} 01^{\prime \prime} \mathrm{S} / 48^{\circ} 15^{\prime} 48^{\prime \prime} \mathrm{W}$ & 27 & & & \\
\hline
\end{tabular}


represent the interrelations between haplotypes using NETWORK 4.6.13 (www.fluxusengineering.com).

\subsection{Microsatellites}

Eight microsatellite loci (XF20, XF26, XF27, XF29, XF31, XF38, XF42, and XF47) of $X$. frontalis were amplified as described by Augusto et al. (2011). Samples were genotyped through capillary electrophoresis on the automatic sequencer ABI 3130 through the service of the Human Genome Research Center of the University of São Paulo.

Microsatellite markers were genotyped using GENEMARKER 2.4.0 (http://www. softgenetics.com).

For characterizing the genetic pool of the four areas and to establish if they could all together be considered a single population, we performed identification of exclusive alleles, calculated allelic diversity, and observed (Ho) and expected (He) heterozygoses per area using GENALEX 6.5 program (Peakall and Smouse 2012) and HardyWeinberg equilibrium (HWE), using GENEPOP 4.1.2 (Rousset 2008). Linkage disequilibrium and $U$ tests were also performed to check for any deviations of HWE using GENEPOP 4.1.2 (Rousset 2008). The significance of linkage disequilibrium was assessed by Bonferroni correction (Rice 1989).

Any genetic differentiation between areas was characterized by unbiased genetic distance (Nei 1978), the construction of principal coordinates analysis charts (PCoA) using genetic distance among individuals in GENALEX 6.5 program (Peakall and Smouse 2012) and the identification of the number of estimated populations $(k)$ using STRUCTURE 2.3.3 software (Pritchard et al. 2000 ) with a configuration of 10,000 cycles and 500,000 repetitions of the Markov chain Monte Carlo (MCMC). The model analyzed was "correlated allele frequencies" which "assumes that the populations all diverged from a common ancestral population at the same time, but allows that the populations may have experienced different amounts of drift (due to different effective population sizes) since this divergence event" (Falush et al. 2003). We also estimated the best $k$ to proceed with the analysis by using the program STRUCTURE HARVESTER (Evanno et al. 2005). Finally, the alignment of ten repetitions resulting from STRUCTURE was performed using the program CLUMPP 1.1.2 (Jakobsson and Rosenberg 2007). The graph of CLUMPP results was generated using the DISTRUCT 1.1 program (Rosenberg 2004). A Mantel test between genetic distances and geographical distances was performed using GENALEX 6.5 (Peakall and Smouse 2012) to assess isolation by distance related to the recent dispersion of alleles. The program BOTTLENECK 1.2.02 (Piry et al. 1999) was used to check if any recent bottleneck event could have occurred in the area. Parameters for the analysis were set according to Santiago et al. (2016). We used the two-phase model (TPM) of mutation with a proportion of stepwise mutation model of $95 \%$ with 10,000 iterations. Wilcoxon sign-rank test was used to highlight any significant deviation.

\section{RESULTS}

\subsection{Mitochondrial DNA}

From the 64 samples, only 54 amplified the expected fragment size from the COI gene. We found 29 mutations among the aligned sequences, seven transitions $(A-G), 18$ transitions $(T-C)$, three transversions $(\mathrm{A}-\mathrm{T})$, and one substitution H (A, C, or T). All substitutions observed were synonymous. The haplotype diversity was $84.8 \%$, and the nucleotide diversity was $11.4 \%$. We found 17 haplotypes from which 12 were exclusive: ALEF (H4, H9, H11, H12, H15, and H16), GEF (H2 and H10), ESP (H13 and H17), and UFUUMU (H8 and H14). We did not observe haplotypes shared by the four study areas. The remaining haplotypes ( $\mathrm{H} 1, \mathrm{H} 3, \mathrm{H} 5, \mathrm{H} 6$, and H7) were observed in two or three study areas. In the haplotype network, H3 haplotype is the most frequent, representing 19 individuals present in three areas (ALEF, GEF, and ESP) (Figure 1).

The highest and lowest genetic distance (Nei 1978) among the four areas occurred between ALEF-UFU-UMU (2.312) and ESP-GEF (0.041), respectively (Table II). The estimated molecular variance calculated (AMOVA) of genetic composition of the four areas showed that 


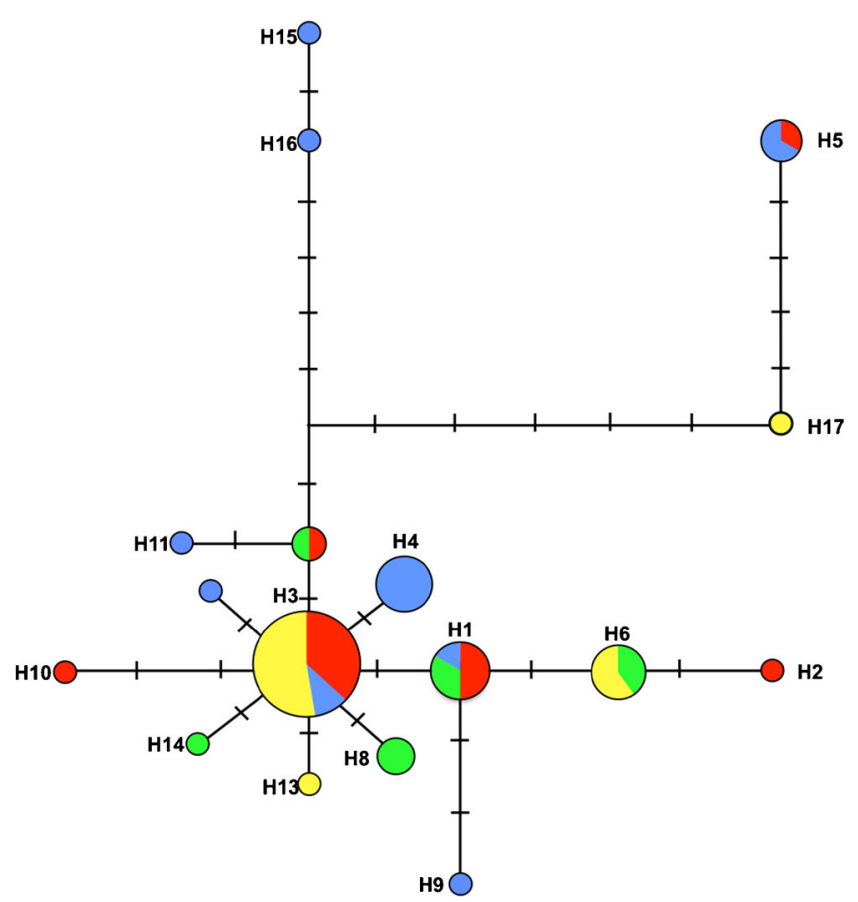

Figure 1. Network relating 17 haplotypes based on 600 bp of cytochrome c oxidase subunit I (COI) mitochondrial DNA sequences from Xylocopa frontalis. Circle sizes represent haplotype frequencies. Vertical bars crossing connector lines represent mutational steps between adjacent haplotypes. Colors represent collection sites: red for GEF (Glória Experimental Farm), yellow for ESP (Ecological Station of Panga), green for UFU-UMU (Universidade Federal de Uberlândia), and blue for ALEF (Água Limpa Experimental Farm).

haplotypic variability is higher within (0.369) areas than between them (0.072). Haplotypes were not grouped together in clades by study area in the maximum likelihood cladogram built from unbiased Nei's genetic distance (data not shown).

\subsection{Microsatellites}

All microsatellite loci were polymorphic with an average number of $9.344 \pm 0.377$ alleles per

Table II. Unbiased genetic distance of Nei (1978) among the studied areas based on mtDNA data (above diagonal) and microsatellites (below diagonal)

\begin{tabular}{lllll}
\hline Study areas & ALEF & GEF & ESP & UFU-UMU \\
\hline ALEF & - & 0.824 & 1.116 & 2.312 \\
GEF & 0.074 & - & 0.041 & 1.237 \\
ESP & 0.000 & 0.053 & - & 1.735 \\
UFU-UMU & 0.054 & 0.124 & 0.113 & - \\
\hline
\end{tabular}

locus (Table III). Exclusive alleles were observed in all study areas (ALEF 20.58\%, GEF 17.64\%, ESP $35.29 \%$, and UFU-UMU 26.47\%).

The calculation of chi-squares and estimation of exact $P$ values by the Markov chain method performed by GENEPOP revealed that only ALEF was not in Hardy-Weinberg equilibrium (Ho $=0.769$, uHe 0.840), (Table III). Also, considering all the study areas and all gene loci, the overall uHe (0.816) was greater than Ho (0.776) and $P$ value was highly significant, which indicates that individuals from the four areas do not constitute a single population in HWE. Furthermore, linkage disequilibrium analysis demonstrated that all loci are inherited independently $(P>0.002$ after the Bonferroni correction). Heterozygotes deficiency, calculated through the $U$ test $(P=0.000)$, may be responsible for deviations from HWE in ALEF.

Our results regarding genetic distance suggest that the study areas ESP and ALEF constitute one subpopulation with genetic distance equal to zero. 
Table III. Observed (Ho) and expected (He) heterozygosity in each study area, chi-square $\left(\chi^{2}\right)$, and $P$ values from $\chi^{2}$ test: ALEF (Água Limpa Experimental Farm), GEF (Glória Experimental Farm), ESP (Ecological Station of Panga), and UFU-UMU (Universidade Federal de Uberlândia)

\begin{tabular}{lllll}
\hline & ALEF & GEF & ESP & UFU-UMU \\
\hline Ho & 0.769 & 0.789 & 0.814 & 0.734 \\
He & 0.840 & 0.802 & 0.830 & 0.790 \\
$\chi^{2}$ & infinity & 18.6303 & 19.2889 & 22.0933 \\
D.F. & 16 & 16 & 16 & 16 \\
$P$ & Highly significant & 0.2883 & 0.2540 & 0.1402 \\
\hline
\end{tabular}

D.F. degrees of freedom

The second lower genetic distance was observed between GEF and ESP (0.053), and the longest distance is between GEF and UFU-UMU study areas (Table II). We did not observe a clustering of genotypes in the PCoA using the unbiased genetic distance (Nei 1978) (Figures 2 and 3). Mantel test showed that genetic and geographical distances were not correlated $\left(R^{2}=0.04473, P=0.25\right)$.

Bayesian analysis (STRUCTURE) supported that $k=2$ is the most likely number of subgroups for the genotypes of all four study areas. However, we did not observe two distinct groups of genotypes on the generated graph from the junction of ten repetitions built by DISTRUCT. This result indicates that the study areas are not structured and all individuals present characteristics of hybrids between two ancestral genotypic groups (Figure 4).

No evidence of recent bottleneck was found after the Wilcoxon signed-rank test or the modeshift test performed by BOTTLENECK 1.2.02 (Piry et al. 1999), with a normal L-shaped curve observed for all four areas.

\section{DISCUSSION}

In the present work, we observed no genetic structure between areas where bee shelters were built for attracting Xylocopa frontalis bees. The genetic diversity observed was high and is comparable to diversity found in other solitary bees such as Andrena vaga (Exeler et al. 2008) and Lasioglossum (Sphecodogastra) oenotherae (Zayed and Packer 2007), even working on a much smaller distribution area. The haplotype network showed a star configuration which is, according to Avise (2000), shown when frequent lineages are widely distributed along exclusive haplotypes locally distributed (Figure 1).

Females of $X$. frontalis present philopatric behavior, i.e., emerging females may remain at same birth location and even reuse the maternal nest (Camillo and Garófalo 1989). Females from one area were not found foraging in other areas, even though it is possible due to their flight range, which could reach $12 \mathrm{~km}$ from the mother nest

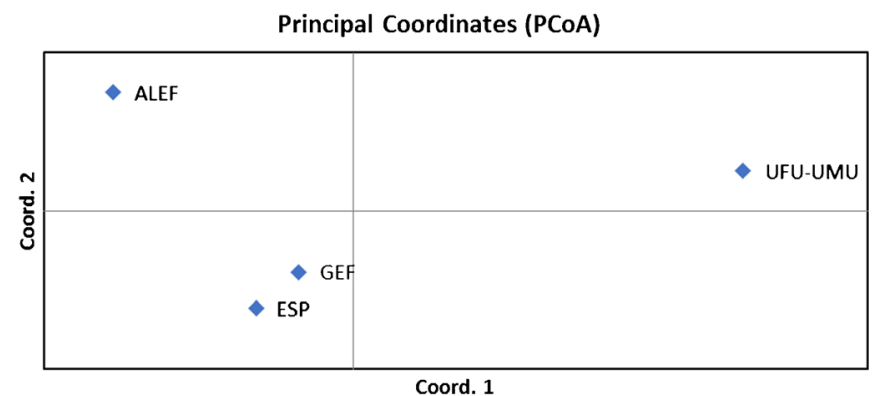

Figure 2. Principal coordinate analysis (PCoA) among collection sites of Xylocopa frontalis based on unbiased genetic distances of Nei (1978) obtained from mtDNA data. 


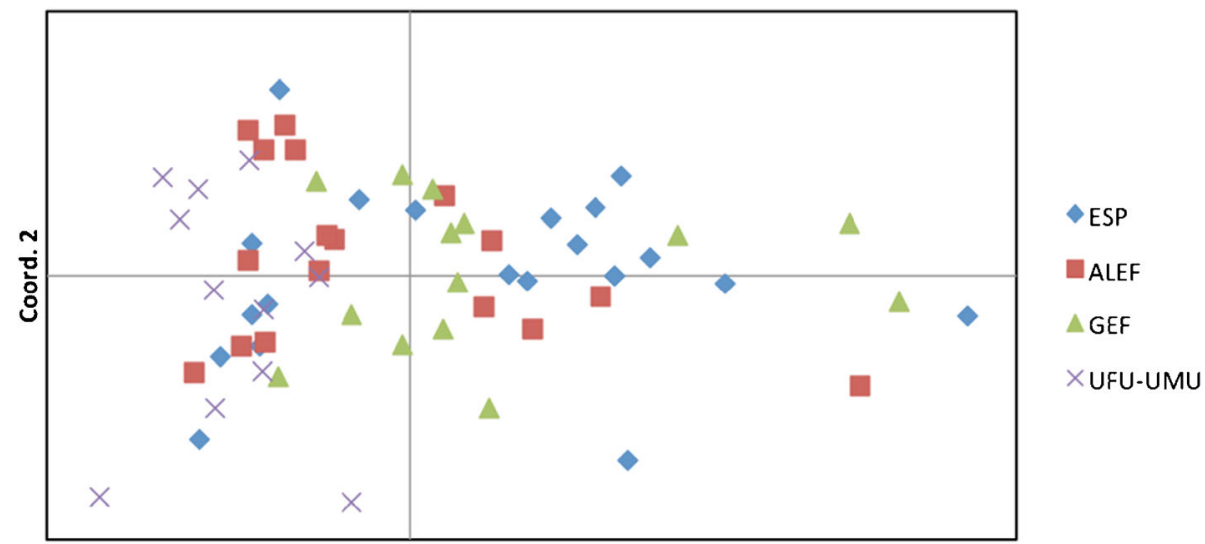

Coord. 1

Figure 3. Principal coordinates analysis (PCoA) among individuals of Xylocopa frontalis based on unbiased genetic distances of Nei (1978) obtained from microsatellite loci genotypic data.

(Freitas and Oliveira-Filho 2001). We believe the wide distribution of the most frequent $\mathrm{H} 3$ haplotype, which is shared among three areas (ALEF, GEF, and ESP), is historical and other haplotypes observed were created by mutations, which have not dispersed yet (Avise 2000). Nevertheless, gene flow through females between areas further than $12 \mathrm{~km}$ apart is possible in a stepping stone model, which assumes subdivision of a large population in colonies, and migrants reach nearby colonies each generation (Kimura and Weiss 1964).

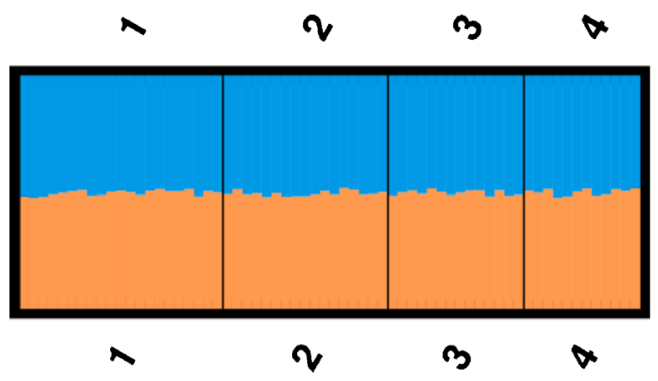

Figure 4. Graphical representation of the genotypic structure of the study areas. $X$-axis (horizontal) bars represent all individuals analyzed, and $Y$-axis (vertical) bars represent $\mathrm{Q}$ values (allocation coefficient of the association of each individual to a particular group of genotypes) estimated for each individual genotype. Orange and blue represent the two genotypic groups $(k=2)$. (1) ALEF (Água Limpa Experimental Farm), (2) GEF (Glória Experimental Farm), (3) ESP (Ecological Station of Panga), and (4) UFU-UMU (Universidade Federal de Uberlândia).
The UFU-UMU was the area that showed the larger genetic distance to the other areas based on mtDNA data. The urban environment surrounding the university could be slightly isolating $X$. frontalis bees from the other countryside areas since these bees show a trend to find new nests next to their mother nests (Whitmore 1997; Antonini et al. 2000). Nevertheless, according to the microsatellite data, gene flow via males was shown to be plausible between UFU-UMU and all other three areas since no structuring has been observed, in spite of this one being potentially more isolated.

The second greatest genetic distant area based on microsatellite data was ALEF in spite of presenting the minority of exclusive alleles. This genetic composition calls our attention, because even though not being isolated from other areas via males, especially from ESP, the area presented the most haplotype diversity (9 from 16 haplotypes) and most of the exclusive haplotypes (50\%). The haplotype sharing with GEF is also intriguing since they are $22 \mathrm{~km}$ apart, which is out of the flight range of Xylocopa bees (Freitas and Oliveira-Filho 2001). However, gene flow via females may also take place through the stepping stone model, as mentioned above (Kimura and Weiss 1964).

The results from STRUCTURE software showed an absence of structuring between all four areas. It might be explained by the overall proximity between areas, since some distances are 
within the flight range of Xylocopa bees, and the higher distances could be connected through other subpopulations in a stepping stone model (Kimura and Weiss 1964). The lack of structuring was also observed for Bombus, a social bee also with a large flight range (Kraus et al. 2009), in a very large sampling area including islands and mainland in Southeastern Brazil (Francisco et al. 2016). In such cases, authors suggested intense gene flow through males and very large populations with high effective numbers of reproductives (Ne) to explain the lack of structuring between areas apart by hundreds of kilometers (Francisco et al. 2016).

In spite of the potential gene flow between all areas observed through microsatellite data, the global analysis in all areas and all loci together showed highly significance for the HWE estimate, which means that all four areas cannot be considered a single population in HWE. Low heterozigozity is probably the main reason for this result, especially in ALEF. Departure of HWE due to inbreeding has been suggested before for southern populations of the solitary bee $L$. (Sphecodogastra) oenotherae (Zayed and Packer 2007) which would be facing bottlenecks after local extinctions. Similar arguments were used to explain low heterozigosity in Colletes floraris populations (Davis et al. 2010).

Our results from BOTTLENECK discard this possibility since ALEF presented the normal Lshaped curve after the Wilcoxon signed-rank test. We believe that heterozigozyte deficiency in ALEF could be due to higher inbreeding, since in this area $X$. frontalis is not an abundant species, according to population studies performed at the southeast Brazil (Yamamoto et al. 2014).

Both markers showed that bees from the four areas are not part of highly structured populations presenting deep genetic differences. Additionally, bees from different areas do not constitute different MUs (Moritz 1994) since no reciprocal monophyly was observed in a fenogram constructed based on mtDNA genetics distance data. According to our results, it would be possible to capture $X$. frontalis bees from one of the areas, possibly the most convenient, and take them on-site to provide pollination services. This kind of management of bees, moving nests from one area to another, can introduce new genes to a population and consequently rescue a declining population from inbreed depression (Walisch et al. 2012).

On the other hand, moving pollinators to agroecosystems has shown in some cases to reduce among-population differentiation, as observed by Liu et al. (2015) in Wiebesia pumilae wasp. The authors observed a discrepancy in gene flow between populations of Ficus and between populations of its pollinator. Wiebesia pumilae populations showed lower gene flow compared with the amount of cross-pollination service provided to the host plant. The author attributed this discrepancy to the manipulation of the pollinators' dispersal behavior. Another effect of the introduction of translocation of wild bees is pathogen spreading, a factor considered a potential causal factor in bees declining (Williams and Osborne 2009).

Most population genetic studies on bees suggest actions for conservation of particular natural populations due to unique genetic characteristics. These studies have addressed the following: the risks of survival due to low genetic diversity (Davis et al. 2010; Francisco et al. 2016), the potential hybridization to close subspecies that could interfere in natural course of speciation (Brito et al. 2014; Francisco et al. 2014), the endemism of haplotypes in important ecologic areas for assorted taxa (Brito and Arias 2010), and the delimitation of MUs in the distribution range of a species (Penha et al. 2015).

Few genetic studies are directed for using bees for pollination purposes, and management plans are nearly inexistent. This study is the first in this direction using Xylocopa bees. Data presented here showed that all bees presented genotypes that could be assigned to any of the four areas, considering that the genetic distances between them are low and no distinct MUs were identified. We propose that Xylocopa bees can be attracted to trap-nests in the four breeding areas and transferred to passion fruit crops close to them. These nest transferences would not interfere in the genetic patrimony of local bees. Nevertheless, we need to add more study areas and to further investigate why ALEF, in spite of not being structured, presented fewer heterozygotes and exclusive haplotypes. According to Packer and Owen (2007), it 
is necessary to assess the number of migrants against mean distances of at least 15 subpopulations to support a conservation plan for bees.

The greatest challenge in using carpenter bees as a pollinator is promoting nesting founding along a controlled selection of genotypes and mating (Keasar 2010), and our work took the first step towards this direction. The gain for passion fruit harvesting has been demonstrated (Junqueira et al. 2012; Junqueira and Augusto 2016), and the use of carpenter bees for pollination services is promising.

\section{ACKNOWLEDGMENTS}

This study was supported by grants from the Conselho Nacional de Desenvolvimento Científico e Tecnológico (CNPq: 457784/2014-8) and Fundação de Amparo à Pesquisa do Estado de Minas Gerais (FAPEMIG; APQ-01708-13). S. C. Augusto received research fellowships from CNPq. We would like to thank Dr. Ana Maria Bonetti for the encouragement and Miriam Clemente Vella for helping with the sampling of some of pretarsals and for DNA extractions.

\section{AUTHOR'S CONTRIBUTIONS}

Jayca and Camila did field work and lab work. Solange did field work. Maria helped with lab work. Rute did lab work and statistical analysis. Jayça, Camila, Solange, and Rute wrote the manuscript.

Accessibilité au contenu génétique de Xylocopa frontalis (Apidae, Xylocopini) en vue d'une gestion durable des services de pollinisation de cette espèce dans les cultures de fruits de la passion

Xylocope / ADNmt / microsatellites / gestion des populations d'abeilles / patrimoine génétique / Brésil

Bewertung des gentischen Zusammenhangs von Xylocopa frontalis (Apidae, Xylocopini) für ein nachhaltiges Bestäubungsmanagement der Passionsfrucht

mtDNA / Mikrosatelliten / Bestäubungsleistung / Management mit Bienen / Brasilien

\section{REFERENCES}

Aizen, M.A., Garibaldi, L.A., Cunningham, S.A., Klein, A.M. (2009) How much does agriculture depend on pollinators? Lessons from long term trends in crop production. Ann. Bot. 103, 1579-1588

Antonini, Y., Jacobi, C.M., Martins, R.P. (2000) Philopatry in the Neotropical Ground-Nesting Solitary Digger Bee Diadasina distinct (Holmner, 1903) (Hymenoptera: Apidae) at a Nesting Site in Southeastern Brazil. Rev. Etol. 2,111-119

Arias, M. C., Atteke, C., Augusto, S. C., Bailey, J., Bazaga, P. et al. (2013) Permanent Genetic Resources added to Molecular Ecology Resources Database 1 February 2013-31 March 2013. Mol. Ecol. Resour. 13, 760-762

Augusto, S.C., Gonçalves, P.H.P., Francisco, F.O., Santiago, L.R., Françoso, E.A., Suzuki, K.M., Sofia, S.H., Simões, Z.L., Arias, M.C. (2011) Microsatellite loci for the carpenter bee Xylocopa frontalis (Apidae, Xylocopini). Conserv. Genet. Resour. 4, 315-317

Avise, J.C. (2000) Phylogeography: The History and Formation of Species. Harvard University Press, Cambridge.

Brito, R.M., Arias, M.C. (2010) Genetic structure of Partamona helleri (Apidae, Meliponini) from Neotropical Atlantic rainforest. Insectes Soc. 57, 413-419.

Brito, R.M., Francisco F.O., Ho, S.Y.W., Oldroyd, B.P. (2014) Genetic architecture of the Tetragonula carbonaria species complex of Australian stingless bees (Hymenoptera: Apidae: Meliponini). Biol. J. Linnean. Soc. 113, 149-161

Brown M.J.F., Paxton, R.J. (2009) The conservation of bees: a global perspective. Apidologie 40, 410-416

Camillo, E. Polinização do Maracujá. (E. Holos, Ed.) (p. 44). Ribeirão Preto, 2003.

Camillo, E., Garófalo, C.A. (1989) Analysis of the niche of two sympatric species of Bombus (Hymenoptera, Apidae) in southeastern Brazil. J. Trop. Ecol. 5, 81-92

Campbell, L.G., Lee, D., Shukla, K., Waite, T.A., Bartsch, D. (2016) An ecological approach to measuring the evolutionary consequences of gene flow from crops to wild or weedy relatives. Appl. Plant. Sci. 4, 1-7

Davis, E.S., Murray, T.E., Fitzpatrick, N., Brown, M.J.F., Paxton, R.J. (2010) Landscape effects on extremely fragmented populations of a rare solitary bee, Colletes floralis. Mol. Ecol. 19, 4922-4935

Drummond, A.J., Ashton, B., Buxton, S., Cheung, M., Cooper, A., et al. (2010). Geneious v5.1. User's guide and application published at: http://geneious.com (accessed on 26 July 2015)

Ellstrand, N.C., Elam, D.R. (1993) Population genetic consequences of small population-size - Implications for plant conservation. Annu. Rev. Ecol. Syst. 24, 217-242

Evanno, G., Regnaut, S., Goudet, J. (2005) Detecting the number of clusters of individuals using the software STRUCTURE: a simulation study. Mol. Ecol. 14, 2611-2620 
Excoffier, L., Smouse, P.E., Quattro, J.M. (1992) Analysis of molecular variance inferred from metric distances among DNA haplotypes: Application to human mitochondrial DNA restriction data. Genetics 131, 479491

Exeler, N., Kratochwil, A., Hochkirch, A. (2008) Strong genetic exchange among populations of a specialist bee, Andrena vaga (Hymenoptera: Andrenidae). Conserv. Genet., 9, 1233-1241.

Falush, D., Stephens, M., Pritchard, J.K. (2003) Inference of population structure using multilocus genotype data: linked loci and correlated allele frequencies. Genetics $164,1567-1587$

Francisco, F.O, Brito, R.M., Santiago, L.R. et al. (2011) Isolation and characterization of 15 microsatellite loci in the stingless bee Plebeia remota (Apidae: Meliponini). Conserv. Genet. Resour. 3, 417-419

Francisco, F., Santiago, L., Mizusawa, Y., Oldroyd, B., Arias, M. (2014) Genetic structure of social bees in Neotropic continental islands. In: International Union for the Study of Social Insects (IUSSI). Cairns, Australia

Francisco, F.O., Santiago, L.R., Mizusawa, Y.M., Oldroyd, B.P., Arias, M.C. (2016) Genetic structure of island and mainland populations of a Neotropical bumble bee species. J. Insect Conserv. 20, 383-394

Freiria, G.A., Ruim, J.B., De Sousa, R.F., Sofia, S.H. (2012) Population structure and genetic diversity of the orchid bee Eufriesea violacea (Hymenoptera, Apidae, Euglossini) from atlantic forest remnants in Southern and Southeastern Brazil." Apidologie 43: 392-402

Freitas, B.M., Oliveira-Filho, J.H. (2001) Criação racional de mamangavas para polinização em áreas agrícolas. Banco do Nordeste, Fortaleza, BR.

Freitas, B.M., Pinheiro, J.N. (2010) Efeitos sub-letais dos pesticidas agrícolas e seus impactos no manejo de polinizadores dos agroecossistemas brasileiros. Oecol. Aust. 14, 282-298

Goulson, D., Nicholls, E., Botías, C., Rotheray, E.L. (2015) Bee declines driven by combined stress from parasites, pesticides, and lack of flowers. SciencExpress 2010, $1-16$

Heard, T.A. The role of stingless bees in crop pollination (1999) Annu. Rev. Entomol. 44, 183-206

IBGE - Instituto Brasileiro de Geografia e Estatística. (2013) Maracujá: área plantada e quantidade produzida. Brasília, 2013. (Produção Agrícola Municipal, 2013). Available in: <http://www.sidra.ibge.gov. br>.

Jakobsson, M., Rosenberg, N.A. (2007) CLUMPP: a cluster matching and permutation program for dealing with label switching and multimodality in analysis of population structure. Bioinformatics 23 :1801-1806

Junqueira, C. N., Augusto, S. C. (2016) Bigger and sweeter passion fruits: effect of pollinator enhancement on fruit production and quality. Apidologie, 48 (2), 131-140

Junqueira, C.N., Hogendoorn, K., Augusto, S.C. (2012) The use of trap-nests to manage carpenter bees
(Hymenoptera: Apidae: Xylocopini), pollinators of passion fruit (Passifloraceae: Passiflora edulis $\mathrm{f}$. flavicarpa). Ann. Entomol. Soc. Am. 105, 884-889

Junqueira, C.N., Yamamoto, M., Oliveira, P.E., Hogendoorn, K., Augusto, S.C. (2013) Nest management increases pollinator density in passion fruit orchards. Apidologie 44, 729-737

Keasar, A. (2010) Large Carpenter Bees as Agricultural Pollinators Psyche 2010 : 927463 . DOI:10.1155/2010 /927463

Kimura, M., Weiss, G.H. (1964) The Stepping Stone Model of Population Structure and the Decrease of Genetic Correlation with Distance. Genetics 49, 561-576

Kraus, F.B., Wolf, S., Moritz, R.F.A. (2009) Male flight distance and population substructure in the bumblebee Bombus terrestris . J. Anim. Ecol. 78, 247-252

Liu, M. Compton, S., G., Zhang, J., Peng F., Chen, X. (2015) Movements of genes between populations: are pollinators more effective at transferring their own or plant genetic markers? Proc. R. Soc. B 282 , 20150290

Losey, J.E., Vaughan, M. (2006) The Economic Value of Ecological Services Provided by Insects. Bioscience, 56(4), 311-321

Lowenstein, D.M., Matteson, K.C., Minor, E.S. (2015) Diversity of wild bees supports pollination services in an urbanized landscape. Oecologia 179, 811

Meletti, L.M.M. (2011) Avanços na cultura do maracujá no Brasil. Rev. Bras. Frut. 33, 83-91

Moritz, C. (1994) Defining evolutionarily significant units for conservation. Trends Ecol. Evol. 9, 373-375

Nei, M. (1978) Estimation of average heterozygosity and genetic distance from a small number of individuals. Genetics 89, 583-590

Olden, J.D., Poff, N.L., Douglas, M.R,, Douglas, M.E., Fausch, K.D. (2004) Ecological and evolutionary consequences of biotic homogenization. Trends Ecol. Evol. 19, 18-24

Oliveira, R., Schlindwein, C. (2009) Searching for a manageable pollinator for Acerola orchards: the solitary oil-collecting bee Centris analis (Hymenoptera: Apidae: Centridini). J. Econ. Entomol. 102 , 265-273

Packer, L., Owen, R. (2007) Population Genetic Aspects of Pollinator Decline Conservation Ecology : Population Genetic Aspects of Pollinator Decline. Search 5 , 1-24.

Peakall, R., Smouse, P.E. (2012) GenAlEx 6.5: genetic analysis in Excel. Population genetic software for teaching and research-an update. Bioinformatics 28, 2537-2539

Penha RES, Gaglianone MC, Almeida FS, Boff SV, Sofia SH (2015) Mitochondrial DNA of Euglossa iopoecila (Apidae, Euglossini) reveals two distinct lineages for this orchid bee species endemic to the Atlantic Forest. Apidologie. 46(3), 346-358

Pereira, M., Garófalo, C.A. (2010) Biologia da nidificação de Xylocopa frontalis e Xylocopa grisescens (Hymenoptera, Apidae, Xylocopini) em ninhos-armadilha. Oecol. Aust. 14, 193-209

Pimentel, L. D., Santos, C. E. M., Ferreira, A. C. C., Martins, A. A., Júnior, A. M. W. et al. (2009) Custo 
de produção e rentabilidade do maracujazeiro no mercado agroindustrial da Zona da Mata Mineira. Rev. Bras. Frutic. [online]. 31(2) : 397-407

Piry, S., Luikart, G., Cornuet, J.M. (1999) BOTTLENECK: a computer program for detecting recent reductions in the effective population size using allele frequency data. J. Hered. 90, 502-503

Pitts-Singer, T.L., Cane, J.H. (2011) The Alfalfa Leafcutting Bee, Megachile rotundata: The World's Most Intensively Managed Solitary Bee. Annu. Rev. Entomol. 56, 221-237

Potts, C.G., Biesmeijer, C., Kremen, P., Neumann, O., Schweiger, O., Kunin, W.E. (2010) Global pollinator declinestrends, impacts and drivers. Trends Ecol. Evol. 25, 345-353

Pritchard, J., Stephens, M., Donnelly, P. (2000) Inference of population structure using multilocus genotype data. Genetics 155 , 945-959

Rice, W.R. (1989) Analyzing tables of statistical tests. Evolution 43, 223-225

Rosenberg, N.A. (2004) DISTRUCT: a program for the graphical display of population structure. Mol. Ecol. 4,137-138

Rousset, F. (2008) Genepop'007: a complete reimplementation of the Genepop software for Windows and Linux. Mol. Ecol. Resour. 8, 103-106

Rozas, J., Librado, P., Sánchez-DelBarrio, J.C., Messeguer, X., Rozas, R. (2010) DNA Sequence Polymorphism (DnaSP). User's guide and application published at: http://ub.edu/dnasp/ (accessed on 24 July 2015)

Santiago, L.R., Francisco, F.O., Jaffé, R., Arias, M.C. (2016) Genetic variability in captive populations of the stingless bee Tetragonisca angustula. Genetica 144, 397-405

Schiavini I., Araújo G. M. (1989) Considerações sobre a vegetação da Reserva Ecológica do Panga (Uberlândia). Soc. Nat. (Online). 1, 61-66

Simon, C., Frati, F., Beckenbach, A., Crespi, B., Liu, H., Flook, P. (1994) Evolution, Weighting, and Phylogenetic Utility of Mitochondrial Gene Sequences and a Compilation of Conserved Polymerase Chain Reaction Primers. Entomol. Soc. Am. 87, 651-704

Slaa, E. J., Sánchez Chaves, J. A., Malagodi-Braga, K. S., Hofstede, F. E. (2006) Stingless bees in applied pollination: practice and perspectives. Apidologie 37(2), 293-315

Steffan-Dewenter, I., Tscharntke, T. (1999) Effects of habitat isolation on pollinator communities and seed set Oecologia 121 (3), 432-40
Tamura, K., Peterson, D., Peterson, N., Stecher, G., Nei, M., Kumar, S. (2011) MEGA5: Molecular Evolutionary Genetics Analysis using maximum likelihood, evolutionary distance, and maximum parsimony methods. Mol. Biol. Evol. 28, 2731-2739

vanEngelsdorp, D., Meixner, M. D. (2010) A historical review of managed honey bee populations in Europe and the United States and the factors that may affect them. J. Invertebr. Pathol. 103, S80-S95

Velthuis, H.H.W., van Doorn, A. (2006) A century of advances in bumblebee domestication and the economic and environmental aspects of its commercialization for pollination. Apidologie 37, 421-451

Walisch, T.J., Colling G., Poncelet, M., Matthies, D. (2012) Effects of inbreeding and interpopulation crosses on performance and plasticity of two generations of offspring of a declining grassland plant. Am. J. Bot. 99, $1300-1313$

Walsh, P.S., Metzger, D.A., Higuchi, R. (1991) Chelex-100 as a medium for simple extraction of DNA for PCRBased typing from forensic. Biotechniques 10, 506513

Wang, I.J., Bradburd, G.S. (2014) Isolation by environment. Mol. Ecol. 23, 5649-5662

Whitmore, T.C. (1997) Tropical forest disturbance, disappearance, and species loss. In: Laurance, W. F., Bierregaard, R. O. (eds.) Tropical forest remnants: ecology, management, and conservation of fragmented communities, pp. 3-12. University of Chicago Press, Chicago.

Williams P. H., Osborne J. L. (2009) Bumblebee vulnerability and conservation world-wide. Apidologie 40, 367-387

Yamamoto, M., Da Silva, C.I., Augusto, S.C., Barbosa, A.A.A., Oliveira, P.E. (2012) The role of bee diversity in pollination and fruit set of yellow passion fruit (Passiflora edulis forma flavicarpa, Passifloraceae) crop in Central Brazil. Apidologie 43, 515-526

Yamamoto, M., Junqueira, C.N., Barbosa, A.A.A., Augusto, S.C., Olivera, P.E. (2014) Estimating crop pollinator population using mark-recapture method. Apidologie 45(2), 205-14

Zayed, A. (2009) Bee genetics and conservation. Apidologie 40, 237-262

Zayed A, Packer L (2007) The population genetics of a solitary oligolectic sweat bee, Lasioglossum (Sphecodogastra) oenotherae (Hymenoptera: Halictidae). Heredity 99, 397-405 